\title{
Müzik Öğretmeni Adaylarının Piyano Çalgısına Yönelik Tutum Düzeyleri İle Piyano Öğrenme Stilleri Arasındaki İlişkinin İncelenmesi
}

\author{
Discovering The Relationship Between Music Teacher Candidates Attitude Levels For Piano \\ Instruments And Piano Learning Styles
}

\author{
Serkan Demirtaş*
}

\begin{abstract}
Learning has taken place in different ways since the world existed. How learning occurs and what kind of differences are formed has always been tried to be explained. Learning is thought to be important, at this point, determining the learning styles of individuals and analyzing and comparing their attitudes towards an instrument may be an important approach. In this study, it was aimed to determine the piano learning styles of the students of Music Education Department and to compare their attitudes towards the piano lesson. The study is a correlational study that 'Attitude Scale Towards Piano Course' (Tufan \& Güdek, 2008) and 'Pamukkale Piano Learning Style Scale' (Demirtaş \& Süral, 2018) have been applied to 118 students studying in the Pamukkale University, Faculty of Education, Music Education Department. Descriptive statistics such as arithmetic mean, standard deviation, frequency distribution and percentage were used primarily in the analysis of the data. First, gender, high school, regular piano playing year, private piano to analyze whether teacher candidates' learning styles and attitudes towards piano lessons differ according to gender, high school they graduated, regular piano playing year, private piano lesson year, and piano teacher studied. The Kolmogorov-Smirnov test was applied to the variables of the year of taking the course and the piano teacher studied and whether it showed parametric values. For non-parametric values, Mann Whitney U and Kruskall Wallis tests were applied, and in the variables with significant differences in the Kruskall Wallis analysis, Mann Whitney $U$ test was applied to the groups within the variable, in order to see which binary groups were among the significant differences. When the data obtained in the study are examined, it is concluded that there is a moderate level of relation between independent and analytical learning styles, and a low-level relation between dependent and affective learning style among the students' piano learning styles and thesir attitudes towards the piano lesson.
\end{abstract}

Structured Abstract: Learning has manifested itself in different ways since the world existed. It is tried to be explained how learning is and what kind of differences it is formed of. Human beings can be seen as a presence in the world that is keen on learning, researching and trying to direct their life interactively with their environment. It is explained by experts that learning develops in different ways. Considering that the concept of learning varies from person to person, it is necessary to examine the concept of learning styles. It is thought that learning is important and at this point, determining the learning styles of the individual, analysing and comparing the attitude of an individual towards an instrument can be an important approach It

\footnotetext{
* Dr. Öğr. Üyesi, Pamukkale Üniversitesi, Eğitim Fakültesi, Güzel Sanatlar Eğitimi Bölümü Asst. Prof. Dr., Pamukkale University, Faculty of Education, Department of Fine Arts ORCID 0000-0003-3357-6666

sdemirtas@pau.edu.tr

Cite as/ Atıf: Demirtaş, Serkan. (2020). Müzik öğretmeni adaylarının piyano çalgısına yönelik tutum düzeyleri ile piyano öğrenme stilleri arasındaki ilişkinin incelenmesi. Turkish Studies - Education, 15(4), 2549-2566. https://dx.doi.org/10.47423/TurkishStudies.44471

Received/Geliş: 23 June/Haziran 2020

Accepted/Kabul: 27 August/Ağustos 2020

Copyright $($ INTAC LTD, Turkey

Checked by plagiarism software

Published/Yayın: 30 August/Ağustos 2020

CC BY-NC 4.0
} 
is thought that a regulated education about learning styles will be beneficial in terms of achieving targeted achievements. By determining the piano learning styles of the students and evaluating their attitudes towards the piano, it may be possible to conduct education in which a better learning takes place. The aim of this study is to determine the piano learning styles of the students of music education department and to compare them with their attitudes towards the piano lesson. Determining the learning styles, comparing them with the attitudes of the students can increase the quality of the education provided and provide better learning. In this regard, this study is thought to be important. In the light of these thoughts, the problem statement of the study was formed as follows: How is the relationship between the Education Faculty, Music Education Department's students' Piano learning styles and their attitudes towards the piano lesson? According to the problem sentence, sub-problems are formed as follows;

1. How are the frequency distributions of the learning styles included in the research according to the determined variables?

2. What is the distribution of students' piano learning styles and attitudes towards the piano by gender, high school graduated, duration of regularly playing piano, the situation of taking private piano lessons, duration of taking private piano lessons, and the number of piano teachers studied during the education?

3. Is there a significant difference in students' piano learning styles and attitudes towards piano according to high school graduated, duration of regularly playing piano, the situation of taking private piano lessons, duration of taking private piano lessons, and the number of piano teachers studied during the education?

4. What is the relationship between students' learning style scores and piano attitude levels?

The study is a correlational study that ' Attitude Scale Towards Piano Course' (Tufan \& Güdek, 2008) and 'Pamukkale Piano Learning Style Scale' (Demirtaş and Süral, 2018) have been applied to 118 students studying in the Pamukkale University, Faculty of Education, Music Education Department. The research universe consisted of students educating in Pamukkale University, Music Education Department in 20182019 academic year in Denizli province. The Attitude Scale Towards Piano Course, was developed by Tufan and Güdek (2008), was applied to 316 students studying at three different universities. It is stated that factor loads vary between 0.60 and 0.79 . It was observed that Kaiser-Meyer Olkin (KMO) value was a $=0.97$, and the reliability coefficient (Cronbach alpha) was a $=0.97$. Learning Style Scale, "As a result of the KaiserMeyer-Olkin (KMO) test conducted to test the suitability of the data for factor analysis and the adequacy of the size of the sample size of the study, a value of .684 was obtained. This value is seen as a near perfect value and shows that the sample suitability is very high. Descriptive statistics such as arithmetic mean, standard deviation, frequency distribution and percentage were used primarily in the analysis of the data. In order to analyse whether the pre-service teachers' learning styles and attitudes towards piano lessons differ according to gender, high school graduated, duration of regular piano playing, the year of taking private piano lessons, and number of the piano teacher studied, Kolmogorov-Smirnov test was applied whether the variables showed parametric values. For non-parametric values, Mann Whitney U and Kruskall Wallis tests were applied, and in the variables with significant differences in the Kruskall Wallis analysis, Mann Whitney $\mathrm{U}$ test was applied to the groups in the variable in order to see which binary groups were among the significant differences. Pearson Correlation test was used to determine the level and direction of the relations. In this study, it was aimed to determine the learning styles of Pamukkale University Music Education students, to measure and compare their attitudes towards the piano lesson. Because of the examinations, it can be said that the students mostly prefer affective learning style among the piano learning styles. It is seen that there is not a high-level relationship between students' piano learning styles and their attitudes towards piano lessons. There is no significant difference between the students who preferred the independent learning style and the determined variables. Accordingly, it can be said that the variables determined do not make a significant difference on the students who prefer the independent learning style. According to the results of this research, it is concluded that there is a moderate relationship between the piano learning style and the attitude towards the piano lesson. It is observed that students who prefer analytical learning style have a significant difference in favour of students who do not take private piano, and there is no significant difference between the other variables. It is concluded that there is a moderate relationship between analytical learning style and piano attitude. It is seen that the students who prefer dependent learning style have a significant difference on the gender variable in favour of male students. There is no significant difference

Turkish Studies - Education, 15(4) 
between the other variables. It is concluded that there is a low-level relationship between dependent learning style and piano attitude. There is no significant difference between the students who prefer the affective learning style and the determined variables. It was concluded that there is a low level of relationship between affective learning style and piano attitude. When the data obtained in the study are examined, it is concluded that there is a moderate level of relation between independent and analytical learning styles, and a low-level relation between dependent and affective learning style among the students' piano learning styles and their attitudes towards the piano lesson. According to the findings obtained, it can be said that there is not a high level of relationship between the attitudes of pre-service music teachers towards the piano lesson and the piano learning styles. This finding may have occurred for various reasons. During the four years, the bumpy lines of the students in the lessons, their communication with their teachers, their approach to the works they took, their love of the instrument, etc. activities might be some of them. With different sample groups, the effects of piano learning styles on the success in piano lesson or the effects on academic success can be investigated. This research can give other results on different variables with other sample groups.

Keywords: Music Education, Piano Education, Attitude, Learning Styles, Instrument Education.

Öz: Öğrenme kavramı geçmişten günümüze var olan bir kavramdır. Bireydeki öğrenme gelişiminin nasıl olduğu, ne gibi farklılıklarla oluştuğu, açıklanmaya çalışılmaktadır. Müzik öğretmeni adaylarının öğrenme stillerinin belirlenmesi ve bir çalgıya karşı tutumunun incelenip karşılaştırılması önemli bir yaklaşım olabilir. Bu çalışmada Müzik Eğitimi Anabilim Dalı öğrencilerinin piyano öğrenme stillerini belirlemek, piyano dersine yönelik tutumlarını karşılaştırmak amaçlanmıştır. Çalışma Pamukkale Üniversitesi Eğitim Fakültesi Güzel Sanatlar Eğitimi Bölümü Müzik Eğitimi Anabilim Dalı’nda öğrenim gören 118 öğrenciye Tufan ve Güdek, (2008) tarafından geliştirilmiş olan Piyano Dersine Yönelik Tutum Ölçeği, Demirtaş ve Süral, (2018) tarafından geliştirilen Pamukkale Piyano Öğrenme Stili Ölçeği uygulanmış korelasyonel bir çalışmadır. Verilerin analizinde öncelikle aritmetik ortalama, standart sapma, frekans dağılımı ve yüzdelik gibi betimsel istatistiklerden yararlanılmıştır. Öğretmen adaylarının öğrenme stillerinin ve piyano dersine yönelik tutumlarının cinsiyet, mezun olduğu lise, düzenli piyano çalma yılı, özel piyano dersi alma yılı ve çalışılan piyano öğretmenine göre farklılık gösterip göstermediğini analiz etmek için öncelikle cinsiyet, mezun olduğu lise, düzenli piyano çalma yılı, özel piyano dersi alma yılı ve çalışılan piyano öğretmeni değişkenlerine Kolmogorov- Smirnov testi uygulanarak parametrik değerler gösterip göstermediği test edilmiştir. NonParametrik değer gösterenler için Mann Whitney U ve Kruskall Wallis testleri uygulanmış, Kruskall Wallis analizi sonucu anlamlı fark görülen değişkenlerde ise anlamlı farkın hangi ikili gruplar arasında olduğunu görebilmek için değişken içinde yer alan gruplara sırasıyla Mann Whitney U testi uygulanmıştır. Çalışmada elde edilen veriler incelendiğinde, öğrencilerin piyano öğrenme stilleri ile piyano dersine yönelik tutumları arasında Bağımsız ve analitik öğrenme stilinde orta düzeyde, bağımlı ve duyuşsal öğrenme stilinde ise düşük düzeyde bir ilişki bulunduğu sonucu ortaya çıkmaktadır.

Anahtar Kelimeler: Müzik Eğitimi, Piyano Eğitimi, Tutum, Öğrenme Stilleri, Çalgı Eğitimi.

\section{Giriş}

İnsanoğlu dünya üzerinde öğrenmeye meraklı, araştıran ve bulunduğu çevre ile etkileşimli olarak hayatına yön vermeye çalışan bir varlıktır. Öğrenmenin farklı şekillerde geliştiği uzmanlar tarafından açıklanmaktadır. Öğrenmenin tanımı Senemoğlu'na göre (2005, s. 92) şöyle yapılmaktadır. "Bireyin kendi yaşantısı yoluyla davranışlarında meydana gelen değişme" bu tanıma göre bireyin kendi yaşantısı yaşadığı toplum ve çevre gibi değişkenler ile farklılık göstermesi, bu bağlamda farklı öğrenme biçimleri oluşması olağan görülebilir. Öğrenciler uzun çalışmalar sonucunda öğrenememekten yakınırlar. Buradaki problem öğrencilerinin nasıl öğreneklerini bilmemelerinden kaynaklanmaktadır (Ertem, 2014). Öğrenme kavramı kişiden kişiye değişiklik gösterdiği düşünüldüğünde öğrenme stilleri kavramını incelemek gerekir.

Öğrenme Stili yaklaşımının Rita Dunn 1960 yıllarında incelediği görülmektedir. (Boydak, 2007). Ortaya atılan bu konu eğitimcilerin ve farklı disiplinlerdeki araştırmacıların ilgisini çekmiş ve üzerine birçok araştırma yapılmıştır. (Aşkar ve Akkoyunlu, 1993; Gencel, 2007; Koçak, 2007; 
Zahal, 2014). Öğrenme Stilleri Dunn'a göre (1993) öğrencilerin bilgileri öğrenmeye çalışırken, kendilerine ait yollar belirlemeleri biçiminde tanımlanabilir (Akt. Boydak, 2007). Öğrenme Stillerinde bireyin ne öğrendiği değil nasıl öğrendiği önemlidir. Öğrenme stili Felder ve Silvermann'a göre (1988) "bireylerin bilgiyi alma, tutma ve işleme sürecindeki karakteristik güçlülük ve tercihler" olarak açıklanmaktadır (Akt. Veznedaaroğlu ve Özgür, 2005, s.1). Öğrenme stili değerlendirilerek yapılan bir eğitim, daha yararlı ve etkili olabilir.

Öğrenme kavramı ile birlikte bireyin öğrenme stillerinin belirlenmesi ve bir çalgıya karşı tutumunun incelenip karşılaştırılması önemli bir yaklaşım olabilir. Müzik öğretmeni adaylarının piyano dersi ile ilgili olarak tutumlarının incelenmesi, piyano eğitimi bakımından ve öğrencilerin daha başarılı olması açısından önemli görülmektedir (Tufan ve Güdek, 2008).

Tutum kelimesi incelendiğinde birçok farklı tanımın yapıldığı görülmektedir. 19. yy’da incelendiği görülen tutum kelimesi, Latince'de harekete hazır anlamına gelmektedir (Arkonaç, 2001). Thurstone'a göre (1931) olumlu ya da olumsuz yoğunluk siralamasina psikolojik nesneye yönelen sıralamasıdır (akt. Tavşancıl, 2014). Freedman, Sears ve Carlsmith 'e göre (1993) tutum, bilişsel, duyuşsal ve davranışsal bir yaklaşım içerisinde olan daimi bir sistemdir (akt. Tavşancıl, 2014). Farklı disiplinlerde tutum kavramının kendi bilim dallarındaki yapılara göre açıklandığ 1 görülmektedir.

Kurtuldu ve Aksu (2015) yaptıkları çalışmada, 164 müzik öğretmeni adayına Türkçe geçerlik ve güvenirliği Aşkar ve Akkoyunlu (1993) tarafından yapılmış "Kolb Öğrenme Stilleri Envanteri" uygulamışlardır. Bu çalışmanın sonucunda, müzik öğretmeni adaylarının değiştiren, benimseyen öğrenme stillerini tercih ettikleri sonucuna ulaştıklarını ifade etmişlerdir. Çalışmada incelenen değişkenlerden cinsiyet değişkeninde anlamlı fark olduğu sonucuna ulaştıkları görülmektedir. Öğrenme Stillerini incelemek ve bu stillere göre yapılacak bir eğitimin, ortaya çıkan sonuçların daha iyi olacağını göstereceği düşünülebilir.

Sır, Karataş ve Çeliköz'ün (2015) çalışmalarında, Matematik, Müzik, Beden Eğitimi, Türkçe, Fen Bilgisi öğretmenliğinde öğrenim gören öğretmen adaylarının öğrenme stillerinin ne olduğu, cinsiyet ve sınıf düzeyi incelenerek değişiklik gösterip göstermediğini incelemişlerdir. 590 öğretmen adayına Seval Fer (2003) tarafından Türkçeye uyarlanan Felder- Silverman (1996) tarafından geliştiren öğrenme stili envanterini uyguladıkları görülmüştür. Çalışmalarının sonucunda yansıtan öğrenme stili, duyumsal öğrenme stili, görsel ve bütünsel öğrenme stillerini daha fazla tercih ettikleri, cinsiyetin değişkeninin öğrenme stilli olarak duyumsal/sezgisel boyutununda anlamlı fark çıktığını, diğer boyutlarda etkili olmadığını, bölüm değişkeninin bütün boyutlarda öğrenme stili tercihini etkilediği, sınıf düzeyi değişkeninin aktif-yansıtan ve görsel/sözel boyuta ait puanlarda etkisinin olduğu sonucuna ulaştıklarını ifade etmişlerdir (Sır,Karataş,Çeliköz, 2015).

Müzik öğretmeni olma yolunda ilerleyen bireylerin piyano dersi ile ilgili olarak tutum incelemesi, piyano programı ve öğrenci açısından başarının artması bakımından önemli görülebilir. (Tufan ve Güdek, 2008).

Bu çalışmanın amacı, müzik öğretmeni adaylarının piyano öğrenme stillerini belirlemek ve öğrencilerin piyano öğrenme stilleri ile piyano dersine yönelik tutumlarını karşılaştırmaktır. Sonuç olarak öğrenme stilleri ile ilgili düzenlenmiş bir eğitimin, yapılmak istenen, hedeflenen kazanımlara ulaşılması bakımından faydalı olacağı düşünülmektedir. Öğrencilerin piyano öğrenme stillerinin belirlenmesi ve piyanoya dersine yönelik tutumlarının değerlendirilmesiyle daha iyi bir öğrenmenin oluşacağı bir eğitim mümkün olabilir. Bu düşünceler 1şığında araştırmanın problem cümlesi: Eğitim Fakültesi Güzel Sanatlar Eğitimi Bölümü Müzik Eğitimi Anabilim Dalı öğrencilerinin Piyano öğrenme stillerinin piyano dersine yönelik tutumları ile ilişkisi ne düzeydedir?

Problem cümlesine göre alt problemler şöyle oluşturulmuştur; 

nasildır?

1. Öğrencilerin öğrenme stillerinin belirlenen değişkenlere göre frekans dağılımları

2. Öğrencilerin piyano öğrenme stilleri ile piyanoya karşı tutumlarının, cinsiyet, mezun olduğu lise, düzenli piyano çalışma yılı, özel piyano dersi alma durumu, özel piyano dersi alma yılı, Eğitimi süresince çalışılan piyano öğretmeni sayısı değişkenlerine göre dağılımı ne düzeydedir?

3. Öğrencilerin piyano öğrenme stilleri ile piyanoya karşı tutumlarında, cinsiyet, mezun olduğu lise, düzenli piyano çalışma yılı, özel piyano dersi alma durumu, özel piyano dersi alma y1lı, eğitimi süresince çalış1lan piyano öğretmeni sayısı değişkenlerine göre, anlamlı bir farklılık var midir? düzeydedir?

4. Öğrencilerin öğrenme stil puanları ile piyano tutum düzeyleri arasındaki ilişki ne

\section{Yöntem} alınmıştır.

Bu makalenin etik kurul izni 03.06.2020 tarihinde 68282350/2018/G04 sayı no lu yazıyla

\section{Araştırmanın Modeli}

Araştırma Pamukkale Üniversitesi Eğitim Fakültesi Güzel Sanatlar Eğitimi Bölümü Müzik Eğitimi Anabilim Dalı'nda olan 118 öğrenciye Tufan ve Güdek'in, (2008) geliştirdikleri Piyano Dersine Yönelik Tutum Ölçeği, Demirtaş ve Süral'in, (2018) geliştirdikleri Pamukkale Piyano Öğrenme Stili Ölçeği uygulanmış korelasyonel bir araştırmadır. "Korelasyonel araştırma, iki ya da daha çok değişken arasındaki ilişkinin herhangi bir şekilde bu değişkenlere müdahale edilmeden incelendiği araştırmalardır” (Büyüköztürk, Çakmak, Akgün, Karadeniz, Demirel, 2015, s.184).

\section{Araştırmanın Evreni}

$\mathrm{Bu}$ araştırma evrenini Denizli ili Pamukkale Üniversitesi Müzik Eğitimi Anabilim Dalı 2018-2019 eğitim öğretim yılı öğrencilerinden oluşmuştur. Toplam 118 öğrenci yer almıştır.

\section{Veri Toplama Aracı}

Araştırmanın evrenine, Piyano Dersine Yönelik Tutum Ölçeği, Pamukkale Piyano Öğrenme Stili Ölçeği uygulanarak veriler elde edilmiştir. Tutum ölçeği, üç farklı üniversitede öğrenimine devam eden 316 öğrenciye uygulanmış. 0.60 ile 0.79 aralarında değiştiği görülen faktör yükü, a $=0.97$ Kaiser-Meyer Olkin değeri, güvenirliği hesaplanan iç tutarlık katsayısı Cronbach alpha değerininde $a=0.97$ olduğu görüldüğ̈̈ ifade edilmiştir (Tufan ve Güdek, 2008). Ölçeği oluşturan maddelerden 1-2-3-6-7-8-10-12-14-15-17-18-20-22-23-25-27-28 hoşnutluk alt boyutunu, 4-5-9-11-13-16-19-21-24-26-29-30 değer alt boyutunu ölçmektedir. Yapılan değerlendirme neticesinde 39 maddeden oluşan deneme ölçeğinden 9 madde ölçekten çıkarıldı ̆̆ , ölçekteki maddelerin 12'si olumsuz 18 'i olumlu olmak üzere toplam 30 maddeden oluştuğu ifade edilmiştir (Tufan ve Güdek, 2008).

Öğrenme Stili Ölçeği, "Verilerin faktör analizine uygunluğu ve çalışmanın yapıldığı örneklem sayısının büyüklügünün yeterliliğini test etmek için yapılan Kaiser-Meyer-Olkin (KMO) testi sonucunda .684 değeri elde edilmiştî" Demirtaş, Süral, 2018, s.95). Ölçeğin dört faktörde toplandığı, bu faktörlerin, bağımsız, analitik, bağımlı, duyuşsal öğrenme stilleri olduğu ifade edilmiştir. Bağımsız öğrenme stilini oluşturan maddelerin, (1-5-9-13-17-21-25-29), analitik öğrenme stilini oluşturan maddelerin, (2-6-10-14-18-22-26), bağımlı öğrenme stilini oluşturan maddelerin, (3-7-11-15-19-23-27-30), duyuşsal öğrenme stilini oluşturan maddelerin, (4-8-12-1620-24-28) şeklinde oluştuğu görülmektedir. 


\begin{tabular}{|c|c|c|c|}
\hline \multicolumn{2}{|c|}{ Değişkenler } & Frekans & Yüzde \\
\hline \multirow{2}{*}{ Cinsiyet } & $\mathrm{K} 1 \mathrm{z}$ & 64 & 54.2 \\
\hline & Erkek & 54 & 45.8 \\
\hline \multirow{2}{*}{ Mezun Olduğu Lise } & Güzel Sanatlar & 86 & 72.9 \\
\hline & Diğer & 32 & 27.1 \\
\hline \multirow{3}{*}{$\begin{array}{l}\text { Düzenli Piyano } \\
\text { Çalma Y1lı }\end{array}$} & $1-3$ y1l & 40 & 33.9 \\
\hline & $4-6$ y1l & 43 & 36.4 \\
\hline & 7 ve üzeri & 35 & 29.7 \\
\hline \multirow{2}{*}{$\begin{array}{l}\text { Özel Piyano Dersi } \\
\text { Alma Durumu }\end{array}$} & Hayır & 104 & 88.1 \\
\hline & Evet & 14 & 11.9 \\
\hline \multirow{5}{*}{$\begin{array}{c}\text { Özel Piyano Dersi } \\
\text { Alma Y1lı }\end{array}$} & Hiç & 104 & 88.1 \\
\hline & $1 \mathrm{y} 1 \mathrm{l}$ & 6 & 5.1 \\
\hline & $2 \mathrm{y} 1 \mathrm{l}$ & 3 & 2.6 \\
\hline & 3 yil & 2 & 1.7 \\
\hline & 4yıl ve üzeri & 3 & 2.5 \\
\hline \multirow{5}{*}{$\begin{array}{l}\text { Eğitimi Süresince } \\
\text { Çalı̈slan Piyano } \\
\text { Öğretmeni }\end{array}$} & Tek Öğrt. & 17 & 12.5 \\
\hline & 2 Öğrt. & 43 & 19.0 \\
\hline & 3 Öğrt. & 31 & 24.1 \\
\hline & 4 Öğrt. & 20 & 22.8 \\
\hline & 5 Ögrrt. & 7 & 21.6 \\
\hline \multicolumn{2}{|l|}{ TOPLAM } & 118 & 100 \\
\hline
\end{tabular}

Tablo 1'e göre cinsiyet değișkeninin kızlarda ( $f=64)$ fazla olduğu, erkeklerde $(f=54)$ daha az olduğu görülmektedir. İkinci değişken olan mezun olduğu lise değişkenine bakıldığında, Güzel Sanatlar Lisesi'nin $(\mathrm{f}=86)$ diğer lise $(\mathrm{f}=32)$ mezunlarına oranla daha çok olduğu görülmüştür. Üçüncü değişken olan düzenli piyano çalma yılı incelendiğinde 1-3 y1l, 4-6 yıl, 7 yıl ve üzeri olarak belirlenen değişkenlerde en fazla 4-6 yıl $(\mathrm{f}=43)$ daha sonra 1-3 y1l $(\mathrm{f}=40)$ son olarak 7 yıl ve üzeri ( $\mathrm{f}=35$ ) biçiminde sıralandığı söylenebilir. Özel piyano dersi alma durumu değişkenine bakıldığında almayan öğrencilerin ( $\mathrm{f}=104)$ alan öğrencilere $(\mathrm{f}=14)$ oranının oldukça fazla olduğu görülmektedir. Özel piyano dersi almış kişiler incelendiğinde, 1 yıl ders alanların 6, 2 yıl ders alanların 2, 3 yıl ders alanların 24 yıl ve üzeri ders alanların 3 olduğu görülmektedir. Araştırmanın beşinci değişkeni olan çalışılan piyano öğretmeni değişkenine bakıldığında, tek öğretmen $(f=17) 2$ öğretmen ( $(\mathrm{f}=43)$, kendi içinde birbirinden uzak bir dağ 1 lım gösterirken; 3 öğretmen $(\mathrm{f}=31), 4$ öğretmen ( $f=20), 5$ öğretmen ( $f=7$ ) ile çalışmış kişilerin arasında çok dengeli bir dağılım olmadı $\breve{g} 1$ görülmektedir. 
Tablo 2: Piyano Dersine Yönelik Tutum Ölçeği Ve Öğrenme Stilleri Ölçeğinin Güvenirlik Katsayilar1

\begin{tabular}{lc}
\hline \multirow{1}{*}{ Ölçek } & Kişi Sayısı $=118$ \\
\cline { 2 - 3 } & Güvenirlik Kayısı \\
\hline $\begin{array}{l}\text { Bağımsız Öğrenme Stili Alt } \\
\text { Boyutu }\end{array}$ & .779 \\
\hline $\begin{array}{l}\text { Analitik Öğrenme Stili Alt } \\
\text { Boyutu }\end{array}$ & .735 \\
\hline $\begin{array}{l}\text { Bağımlı Öğrenme Stili Alt } \\
\text { Boyutu }\end{array}$ & .779 \\
\hline $\begin{array}{l}\text { Duyuşsal Öğrenme Stili Alt } \\
\text { Boyutu }\end{array}$ & .736 \\
\hline $\begin{array}{l}\text { ÖĞRENME STiLİ GENEL } \\
\text { Piyano Tutum Hoşnutluk }\end{array}$ & .775 \\
\hline Piyano Tutum Değer & .910 \\
\hline PİYANO TUTUM GENEL & .965 \\
\hline
\end{tabular}

Tablo 2'ye göre Bağımsız Öğrenme Stili güvenirlik katsayısı .779, Analitik Öğrenme Stili .735, Bağımlı Öğrenme Stili .779, Duyuşsal Öğrenme Stili .736, Genel Öğrenme Stili .775, Piyano Tutum Ölçeği Hoşnutluk alt boyutu güvenirliği .910, değer güvenirliği . 965, tutum boyutunun genel güvenirliği .965 olduğu görülmektedir. Atılgan, Kan ve Doğan’a (2015) göre, güvenirlik 0.00 ile +1.00 arasında farklı değerler alır. Güvenirlik indeksinin -1.00 çıkması mükemmel bir güvenirliği, bu nedenle hatasız bir ölçmeyi, 0.00 çıkması tamamıla güvenilir olmayan, tümüyle hatalardan oluşmuş bir ölçme sonucunu ortaya çıkarır. Can'a (2014) göre belirtilen değerlerin güvenilir olduğu görülmektedir.

\section{Verilerin Analizi}

Verilerin analizinde öncelikle, standart sapma, aritmetik ortalama, yüzdelik, frekans dağılımı gibi betimsel istatistiklerden faydalanılmıştır. Öğretmen adaylarının öğrenme stillerinin ve piyano dersine yönelik tutumlarının cinsiyet, mezun olduğu lise, düzenli piyano çalma yılı, özel piyano dersi alma yılı ve eğitimi süresince çalışılan piyano öğretmenine göre farklılık olup olmadığını analiz etmek için cinsiyet, mezun olduğu lise, düzenli piyano çalma yılı, özel piyano dersi alma yılı ve eğitimi süresince çalışılan piyano öğretmeni değişkenlerine KolmogorovSmirnov testi yapılarak parametrik değer olup olmadığı incelenmiştir. Parametrik olmayan değer gösterenler için Mann Whitney U ve Kruskall Wallis analizleri uygulanmış, Kruskall Wallis analizi sonucu anlamlı fark görülen değişkenlerde ise anlamlı farkın hangi ikili gruplar arasında olduğunu görebilmek için değişken içinde yer alan gruplara sırasıyla Mann Whitney U testi yapılmıştır. İlişkilerin düzey ve yönünü belirlemek Pearson Korelasyon testi uygulanarak ortaya koyulmaya çalışılmıştır. Verilerin analizlerinde bir istatistik programı kullanılmıştır.

\section{Bulgular}

\section{Araştırmanın Birinci Alt Problemine Ait Bulgular ve Yorum}

Araştırmanın birinci alt problemi "Araştırma kapsamında yer alan öğrenme stillerinin belirlenen değişkenlere göre frekans dağılımları nasıldır?” biçiminde oluşturulmuştur. 
Tablo 3: Öğrenme Stillerinin Belirlenen Değișkenlere Göre Dağglımı

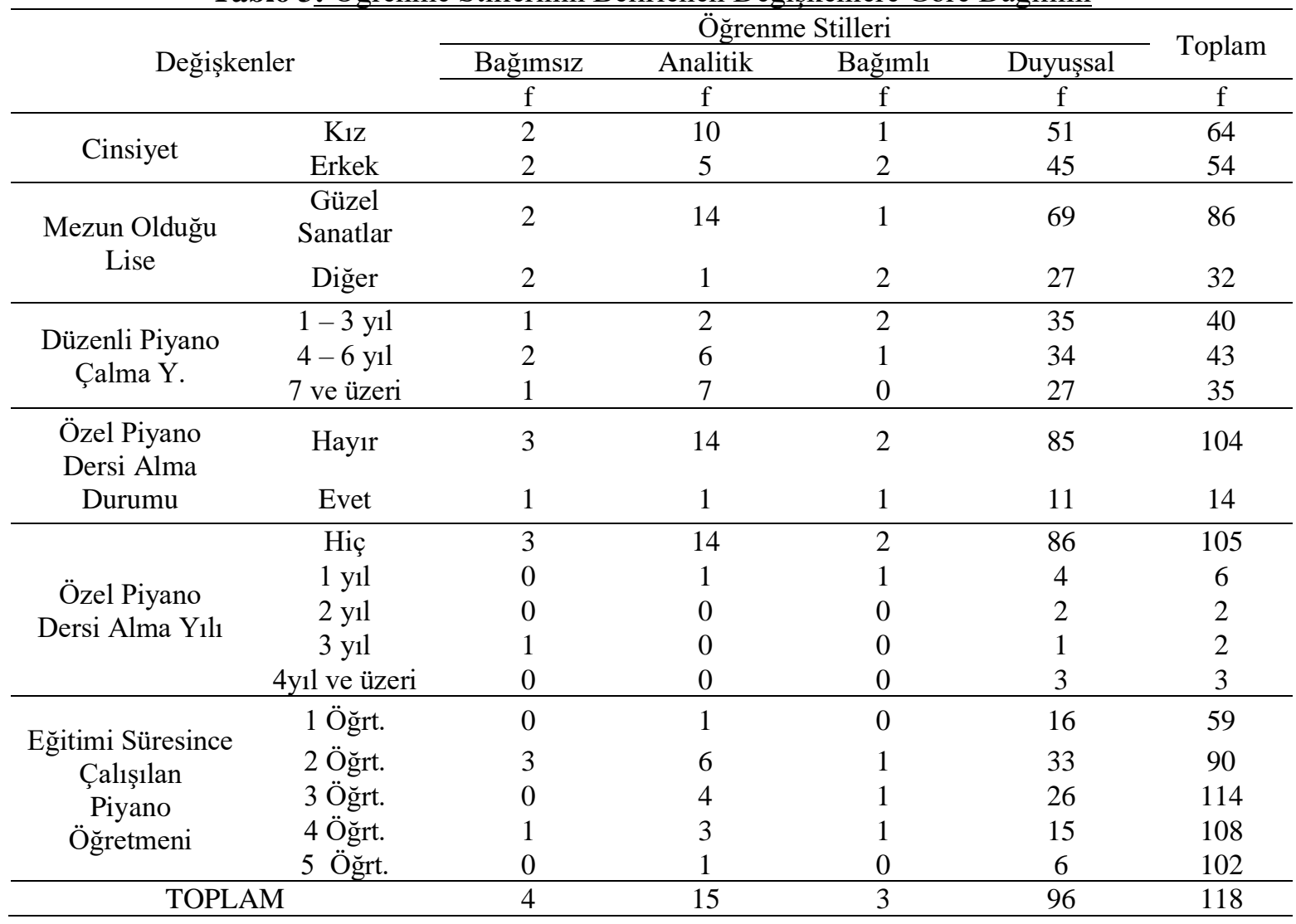

Araştırmanın birinci alt probleminde, öğrenme stillerinin belirlenen değişkenlere göre dağılımı incelenmiştir. Bu dağılıma göre, cinsiyet değişkeninde duyuşsal öğrenme stilinde ( $\mathrm{f}=96)$ yığglma olduğu görülmektedir. Duyuşsal öğrenme stilinde kız öğrencilerin erkek öğrencilerden daha fazla olduğu söylenebilir. Analitik öğrenme stilinin ( $\mathrm{f}=15$ ) Duyuşsal öğrenme stilinden sonra tercih edilen diğer bir öğrenme stili olduğu görülmektedir. Diğer iki değişkenin "bağımsız-bağımlı" daha az tercih edildiği ve dengeli dağılıma gösterdiği söylenebilir.

Araştırmanın mezun olunan değişkenine bakıldığında, Duyuşsal öğrenme stilinin daha fazla tercih edildiği ve bu tercihte Güzel Sanatlar Lisesi mezunu ( $\mathrm{f}=86)$ öğrencilerin Diğer lise mezunu ( $\mathrm{f}=32)$ öğrencilere oranla daha fazla olduğu tespit edilmiştir. Bağımsız öğrenme stilinde Güzel Sanatlar Lisesi mezunu ( $\mathrm{f}=2$ ) öğrencileri, diğer lise mezunu ( $\mathrm{f}=2)$ öğrenciler ile dağılımının eşit olduğu görülmektedir. Analitik öğrenme stilinde güzel Sanatlar lisesi mezunu ( $f=14)$ öğrencilerin diğer lise mezunu ( $\mathrm{f}=1)$ öğrencilere oranının daha fazla olduğu görülmektedir. Bağımlı öğrenme stilini tercih eden öğrencilerin daha az olduğu söylenebilir.

Diğer değişken özel piyano dersi alma durumu incelendiğinde, almayan öğrencilerin ( $\mathrm{f}=85)$ alan öğrencilere ( $\mathrm{f}=11)$ oranın fazla olduğu ve duyuşsal öğrenme stilini tercih ettikleri görülmektedir. $\mathrm{Bu}$ değişkende bağımsız ve bağımlı öğrenme stillerinin dengeli bir dağılım gösterdiği söylenebilir. Analitik öğrenme stilini tercih eden öğrencilerin, özel ders alan sayısı 14, almayan sayısı 1 olduğu görülmektedir.

\section{Araştırmanın İkinci Alt Problemine Ait Bulgular ve Yorum}

Araştırmanın ikinci alt problemi "Öğrencilerin piyano öğrenme stilleri ile piyanoya karşı tutumlarının, cinsiyet, mezun olduğu lise, düzenli piyano çalışma yıll, özel piyano dersi alma durumu, özel piyano dersi alma yılı, Eğitimi süresince çalışılan piyano öğretmeni sayısı değişkenlerine göre dağılımı ne düzeydedir?” biçiminde oluşturulmuştur. Öncelikle belirlenen 
bağımsız değişkenlerin örneklem grubuna göre nasıl bir dağılım gösterdiğine bakılmıştır. Bunun için Kolmogrov-Smirnov normallik testi uygulanmıştır. Elde edilen sonuçlar tablo 4'de gösterilmiştir.

Tablo 4: Kolmogorov-Smirnov Testi Sonuçları (Normallik Testi)

\begin{tabular}{|c|c|c|c|c|c|c|}
\hline & Cinsiyet & $\begin{array}{l}\text { Mezun } \\
\text { Olduğu } \\
\text { Lise }\end{array}$ & $\begin{array}{c}\text { Düzenli } \\
\text { Piyano } \\
\text { Çalma y1lı }\end{array}$ & $\begin{array}{c}\text { Özel Piyano } \\
\text { Dersi Alma } \\
\text { Durumu }\end{array}$ & $\begin{array}{c}\text { Özel } \\
\text { Piyano } \\
\text { Dersi Alma } \\
\text { Y11 }\end{array}$ & $\begin{array}{c}\text { Ĕgitimi } \\
\text { Süresince } \\
\text { Çalış1lan } \\
\text { Piyano } \\
\text { Öğretmeni } \\
\text { Sayısı } \\
\end{array}$ \\
\hline $\mathrm{N}$ & 118 & 118 & 118 & 118 & 118 & 118 \\
\hline $\begin{array}{l}\text { Kolmogorov- } \\
\text { Smirnov Z }\end{array}$ & .362 & .457 & .223 & .524 & .508 & .226 \\
\hline $\begin{array}{l}\text { Asymp. Sig. (2- } \\
\text { tailed) }\end{array}$ & .000 & .000 & .000 & .000 & .000 & .000 \\
\hline
\end{tabular}

Veri dağılımının normalliği Kolmogorov- Smirvov testi ile incelenmiştir. Test sonucu anlamlı çıktığı için $(\mathrm{p}<.05)$ parametrik olmayan testler uygulanmıştır. (Can, 2014, Büyüköztürk, 2015). Tablo 4'e bakıldığında Kolmogorov-Smirnov testi uygulanmış ve tüm değişkenler .05 düzeyinde anlamlı fark gösterdiği için non-parametrik testler kullanılmıştır. Belirlenen değiş̧kenlerde 2 gruplu olanlara Mann Whitney U testi, 2'den fazla gruba sahip olan değişkenlerde ise Kruskall Wallis testi kullanılmıştır.

\subsection{Araştırmanın Üçüncü Alt Problemine Ait Bulgular ve Yorum}

Araştırmanın üçüncü alt problemi “Öğrencilerin piyano öğrenme stilleri ile piyanoya karşı tutumlarında, cinsiyet, mezun olduğu lise, düzenli piyano çalışma yılı, özel piyano dersi alma durumu, özel piyano dersi alma yılı, eğitimi süresince çalışılan piyano öğretmeni sayısı değişkenlerine göre, anlamlı bir farklılık var mıdır?" biçiminde oluşturulmuştur. Bu araştırma problemine ilişkin olarak cinsiyet değişkenine göre elde edilen bulgular Tablo 5'de gösterilmiştir.

Tablo 5: Bağımsız Öğrenme Stilinin İkili Gruplu Değişkenler Üzerinde Anlamlılık Düzeyi

\begin{tabular}{clcccccc}
\hline Değişkenler & Gruplar & $\mathrm{N}$ & $\begin{array}{c}\text { Sira } \\
\text { Ortalamas }\end{array}$ & Sira Toplamı & $\mathrm{U}$ & $\mathrm{Z}$ & $\mathrm{p}$ \\
\hline \multirow{2}{*}{ Cinsiyet } & Kız & 64 & 57.94 & 3708.0 & 1628.0 & -.541 & .588 \\
& Erkek & 54 & 61.35 & 3313.0 & 1628.0 \\
\hline
\end{tabular}

Bağımsız öğrenme stiline sahip öğrencilerin, cinsiyet değişkeni üzerinde anlamlı bir fark oluşturup oluşturmadığına bakılmıştır. Tablo 5'e göre, anlamlı bir fark $(\mathrm{p}=.588)$ bulunmadığ görülmüştür. Buna göre cinsiyet değişkeninin piyano öğreniminde bağımsız öğrenme stili üzerinde bir fark oluşturmadığ 1 söylenebilir.

Tablo 6: Bağımsız Öğrenme Stilinin İkili Gruplu Değişkenler Üzerinde Anlamlılık Düzeyi

\begin{tabular}{|c|c|c|c|c|c|c|c|}
\hline Değişkenler & Gruplar & $\mathrm{N}$ & $\begin{array}{c}\text { Sira } \\
\text { Ortalamas1 }\end{array}$ & Sira Toplamı & $\mathrm{U}$ & $\mathrm{Z}$ & $\mathrm{p}$ \\
\hline $\begin{array}{l}\text { Mezun Olduğu } \\
\text { Lise }\end{array}$ & $\begin{array}{l}\text { Güzel } \\
\text { Sanatlar }\end{array}$ & 86 & 5696 & 4898.50 & 1157.500 & -1.325 & .185 \\
\hline
\end{tabular}

Bağımsız öğrenme stiline sahip öğrencilerin, mezun olduğu lise değişkeni üzerinde anlamlı bir fark oluşturup oluşturmadığına bakılmıştır. Tablo 6'ya göre, anlamlı bir fark $(p=.185)$ 
bulunmadığı görülmüştür. Buna göre mezun olduğu lise değişkeninin piyano öğreniminde bağımsız öğrenme stili üzerinde bir fark oluşturmadığı söylenebilir.

Tablo 7: Bağımsız Öğrenme Stilinin İkili Gruplu Değişkenler Üzerinde Anlamlılık Düzeyi

\begin{tabular}{clcccccc}
\hline Değı̧şkenler & Gruplar & $\mathrm{N}$ & $\begin{array}{c}\text { Sira } \\
\text { Ortalaması }\end{array}$ & Sira Toplamı & $\mathrm{U}$ & $\mathrm{Z}$ & $\mathrm{p}$ \\
\hline Özel Piyano Dersi & Hayır & 104 & 60.72 & 6314.50 & 601.500 & -1.055 & .291 \\
Alma Durumu & Evet & 14 & 50.46 & 706.50 & 601.50 & \\
\hline
\end{tabular}

Bağımsız öğrenme stiline sahip öğrencilerin, özel piyano dersi alma durumu değişkeni üzerinde anlamlı bir fark oluşturup oluşturmadığına bakılmıştır. Tablo 7'ye göre, anlamlı bir fark $(\mathrm{p}=.291)$ bulunmadığ görülmüştür. Buna göre özel piyano dersi alma durumu değişkeninin piyano öğreniminde bağımsız öğrenme stili üzerinde bir fark oluşturmadığı söylenebilir.

Tablo 8: Bağımsız Öğrenme Stilinin İkiden Fazla Gruplu Değişkenler Üzerinde Anlamlılık Düzeyi

\begin{tabular}{cccccccc}
\hline Değiş̧kenler & Gruplar & $\mathrm{n}$ & $\begin{array}{c}\text { Sınıf } \\
\text { Ortalaması }\end{array}$ & sd & $\mathrm{X}^{2}$ & $\mathrm{p}$ & Fark \\
\hline Düzenli Piyano & $1-3$ yıl & 40 & 58.91 & & & & \\
Çalma Y1lı & $4-6$ yıl & 43 & 62.19 & 2 & .486 & .784 & - \\
& 7 ve üzeri & 35 & 56.87 & & & & \\
\hline
\end{tabular}

Tablo 8 incelendiğinde, elde edilen verilerin düzenli piyano çalma yılı değişkeni bağımsız öğrenme stilinde anlamlı fark oluşturmadığı görülmektedir.

Tablo 9: Bağımsız Öğrenme Stilinin İkiden Fazla Gruplu Değişkenler Üzerinde Anlamlılık Düzeyi

\begin{tabular}{clcccccc}
\hline Değişkenler & Gruplar & $\mathrm{n}$ & $\begin{array}{c}\text { Sinıf } \\
\text { Ortalaması }\end{array}$ & $\mathrm{sd}$ & $\mathrm{X}^{2}$ & $\mathrm{p}$ & Fark \\
\hline Eğitimi & 1 Öğgrt. & 17 & 66.06 & & & & \\
Süresince & 2 Öğrt. & 43 & 26.53 & & & & \\
Çalışılan & 3 Öğrt. & 31 & 51.66 & 4 & 4.283 & .269 & - \\
Piyano & 4 Öğrt. & 20 & 64.58 & & & & \\
Öğretmeni & 5 Öğrt. & 7 & 45.14 & & & & \\
\hline
\end{tabular}

Bağımsız öğrenme stilini tercih eden öğrencilerin, Tablo 9'a göre eğitimi süresince çalıştığ1 piyano öğretmeni değişkeninde anlamlı bir fark oluşturmadığı söylenebilir.

Tablo 10. Analitik Öğrenme Stilinin İkili Gruplu Değişkenler Üzerinde Anlamlılık Düzeyi

\begin{tabular}{clcccccc}
\hline Değişkenler & Gruplar & $\mathrm{N}$ & $\begin{array}{c}\text { Sira } \\
\text { Ortalaması }\end{array}$ & Sira Toplamı & U & $\mathrm{Z}$ & $\mathrm{p}$ \\
\hline \multirow{2}{*}{ Cinsiyet } & Kız & 64 & 63.70 & 4077.0 & \multirow{2}{*}{1459.0} & -1.458 & \multirow{2}{*}{145} \\
& Erkek & 54 & 54.52 & 2944.0 & \\
\hline
\end{tabular}

Analitik öğrenme stiline sahip öğrencilerin, cinsiyet değişkeni üzerinde anlamlı bir fark oluşturup oluşturmadığına bakılmıştır. Tablo 10'a göre, anlamlı bir fark $(\mathrm{p}=.145)$ bulunmadığ görülmüştür. Buna göre cinsiyet değişkeninin piyano öğreniminde analitik öğrenme stili üzerinde bir fark oluşturmadığı söylenebilir. 
Tablo 11: Analitik Öğrenme Stilinin İkili Gruplu Değişkenler Üzerinde Anlamlılık Düzeyi

\begin{tabular}{|c|c|c|c|c|c|c|c|}
\hline Değişkenler & Gruplar & $\mathrm{N}$ & $\begin{array}{c}\text { Sira } \\
\text { Ortalamas }\end{array}$ & Sira Toplamı & $\mathrm{U}$ & $\mathrm{Z}$ & $\mathrm{p}$ \\
\hline \multirow{2}{*}{$\begin{array}{l}\text { Mezun Olduğu } \\
\text { Lise }\end{array}$} & Güzel & 86 & 58.10 & 4996.50 & \multirow[b]{2}{*}{1255.500} & \multirow[b]{2}{*}{-.732} & \multirow[b]{2}{*}{.464} \\
\hline & $\begin{array}{l}\text { Sanatlar } \\
\text { Diğer }\end{array}$ & 32 & 63.27 & 2024.50 & & & \\
\hline
\end{tabular}

Analitik öğrenme stiline sahip öğrencilerin, mezun olduğu lise değişkeni üzerinde anlamlı bir fark oluşturup oluşturmadığına bakılmıştır. Tablo 11'e göre, anlamlı bir fark $(p=.464)$ bulunmadığı görülmüștür. Buna göre mezun olduğu lise değişkeninin piyano öğreniminde analitik öğrenme stili üzerinde bir fark oluşturmadığı söylenebilir.

Tablo 12: Analitik Öğrenme Stilinin İkili Gruplu Değişkenler Üzerinde Anlamlılık Düzeyi

\begin{tabular}{|c|c|c|c|c|c|c|c|}
\hline Değişkenler & Gruplar & $\mathrm{N}$ & $\begin{array}{c}\text { Sira } \\
\text { Ortalamas1 } \\
\end{array}$ & Sira Toplamı & $\mathrm{U}$ & $\mathrm{Z}$ & $\mathrm{p}$ \\
\hline $\begin{array}{l}\text { Özel Piyano Dersi } \\
\text { Alma Durumu }\end{array}$ & $\begin{array}{l}\text { Hayır } \\
\text { Evet }\end{array}$ & $\begin{array}{c}104 \\
14\end{array}$ & $\begin{array}{l}61.83 \\
42.18 \\
\end{array}$ & $\begin{array}{c}6430.50 \\
590.50\end{array}$ & 485.500 & -2.025 & .043 \\
\hline
\end{tabular}

Analitik öğrenme stiline sahip öğrencilerin, özel piyano dersi alma durumu değişkeni üzerinde anlamlı bir fark oluşturup oluşturmadığına bakılmıştır. Tablo 12'ye göre, anlamlı bir fark $(\mathrm{p}=.043)$ bulunduğu görülmüştür. Buna göre özel piyano dersi alma durumu değişkeninin piyano öğreniminde analitik öğrenme stili üzerinde bir fark oluşturduğu söylenebilir. Bu farkın ders almayan öğrencilerin lehine olduğu söylenebilir.

Tablo 13: Analitik Öğrenme Stilinin İkiden Fazla Gruplu Değişkenler Üzerinde Anlamlılık Düzeyi

\begin{tabular}{cccccccc}
\hline Değişkenler & Gruplar & $\mathrm{n}$ & $\begin{array}{c}\text { Sınıf } \\
\text { Ortalaması }\end{array}$ & sd & $\mathrm{X}^{2}$ & $\mathrm{p}$ & Fark \\
\hline Düzenli Piyano & $1-3$ yıl & 40 & 61.80 & & & & \\
Çalma Yılı & $4-6$ yıl & 43 & 60.60 & 2 & .705 & .703 & - \\
\hline
\end{tabular}

Tablo 13 incelendiğinde, elde edilen verilerin bağımlı öğrenme stilinde düzenli piyano çalma yılı değişkenine göre anlamlı fark oluşturmadığı görülmektedir.

Tablo 14. Analitik Öğrenme Stilinin İkiden Fazla Gruplu Değişkenler Üzerinde Anlamlılık Düzeyi

\begin{tabular}{clcccccc}
\hline Değişkenler & Gruplar & $\mathrm{n}$ & $\begin{array}{c}\text { Sınıf } \\
\text { Ortalamas }\end{array}$ & $\mathrm{sd}$ & $\mathrm{X}$ & $\mathrm{p}$ & Fark \\
\hline Eğitimi & 1 Öğgrt. & 17 & 57.41 & & & & \\
Süresince & 2 Öğrt. & 43 & 64.02 & & & & \\
Çalış1lan & 3 Öğrt. & 31 & 57.82 & 4 & 2.927 & .570 & - \\
Piyano & 4 Öğrt. & 20 & 60.55 & & & & \\
Öğretmeni & 5 Öğrt. & 7 & 40.21 & & & & \\
\hline
\end{tabular}

Analitik öğrenme stilini tercih eden öğrencilerin, tablo 14'e göre eğitimi süresince çalıştığı piyano öğretmeni değişkeninde anlamlı bir fark $(\mathrm{p}=.570)$ oluşturmadı̆̆ görülmüştür.

Tablo 15: Bağımlı Öğrenme Stilinin İkili Gruplu Değişkenler Üzerinde Anlamlılık Düzeyi

\begin{tabular}{cccccccc}
\hline Değişkenler & Gruplar & $\mathrm{N}$ & $\begin{array}{c}\text { Sira } \\
\text { Ortalamas }\end{array}$ & Sıra Toplamı & $\mathrm{U}$ & $\mathrm{Z}$ & $\mathrm{p}$ \\
\hline \multirow{2}{*}{ Cinsiyet } & Kız & 64 & 51.95 & 3325.0 & 1245.0 & -2.613 & .009 \\
\hline * $\mathrm{p}<0.05$ düzeyinde anlamlı & 54 & 68.44 & 3696.0 & & & &
\end{tabular}


Bağımlı öğrenme stiline sahip öğrencilerin, cinsiyet değişkeni üzerinde anlamlı bir fark oluşturup oluşturmadığına bakılmıştır. Tablo 15 incelendiğinde bağımlı öğrenme stilinde cinsiyet değişkeninin anlamlı bir fark $(\mathrm{p}=009)$ oluşturduğu görülmektedir. Bu farkın erkeklerin lehine çıktığı, erkeklerin kızlara göre daha çok bağımlı ögrenme stilini tercih ettiği söylenebilir.

Tablo 16: Bağımlı Öğrenme Stilinin İkili Gruplu Değişkenler Üzerinde Anlamlılık Düzeyi

\begin{tabular}{|c|c|c|c|c|c|c|c|}
\hline Değişkenler & Gruplar & $\mathrm{N}$ & $\begin{array}{c}\text { Sira } \\
\text { Ortalamasi }\end{array}$ & Sira Toplamı & $\bar{U}$ & $\mathrm{Z}$ & $\mathrm{p}$ \\
\hline \multirow{3}{*}{$\begin{array}{l}\text { Mezun Olduğu } \\
\text { Lise }\end{array}$} & Güzel & 86 & 58.10 & 4996.50 & \multirow{3}{*}{1255.500} & \multirow{3}{*}{-.732} & \multirow{3}{*}{.464} \\
\hline & Sanatlar & & & & & & \\
\hline & Diğer & 32 & 63.27 & 2024.50 & & & \\
\hline
\end{tabular}

Bağımlı öğrenme stiline sahip öğrencilerin, mezun olduğu lise değişkeni üzerinde anlamlı bir fark oluşturup oluşturmadığına bakılmıştır. Tablo 16'ya göre, anlamlı bir fark $(\mathrm{p}=.464)$ bulunmadığ1 görülmüsstür. Buna göre mezun olduğu lise değişkeninin piyano öğreniminde bağımlı ögrenme stili üzerinde bir fark oluşturmadığı söylenebilir.

Tablo 17: Bağımlı Öğrenme Stilinin İkili Gruplu Değişkenler Üzerinde Anlamlılık Düzeyi

\begin{tabular}{clcccccc}
\hline Değişkenler & Gruplar & $\mathrm{N}$ & $\begin{array}{c}\text { Sira } \\
\text { Ortalaması }\end{array}$ & Sıra Toplamı & $\mathrm{U}$ & $\mathrm{Z}$ & $\mathrm{p}$ \\
\hline Özel Piyano Dersi & Hayır & 104 & 60.28 & 6269.00 & \multirow{2}{*}{647.000} & -.675 & .500 \\
Alma Durumu & Evet & 14 & 53.71 & 752.00 & 647 & \\
\hline
\end{tabular}

Bağımlı öğrenme stiline sahip öğrencilerin, özel piyano dersi alma durumu değişkeni üzerinde anlamlı bir fark oluşturup oluşturmadığına bakılmıştır. Tablo 17'ye göre, anlamlı bir fark $(\mathrm{p}=.500)$ bulunmadığı görülmüştür. Buna göre özel piyano dersi alma durumu değişkeninin piyano öğreniminde bağımlı öğrenme stili üzerinde bir fark oluşturmadığı görülmüştür.

Tablo 18: Bağımlı Öğrenme Stilinin İkiden Fazla Gruplu Değişkenler Üzerinde Anlamlılık Düzeyi

\begin{tabular}{cccccccc}
\hline Değiş̧kenler & Gruplar & $\mathrm{n}$ & $\begin{array}{c}\text { Sınıf } \\
\text { Ortalaması }\end{array}$ & $\mathrm{sd}$ & $\mathrm{X}^{2}$ & $\mathrm{p}$ & Fark \\
\hline Düzenli Piyano & $1-3$ yıl & 40 & 61.55 & & & & \\
Çalma Y1lı & $4-6$ y1l & 43 & 62.24 & 2 & .1 .402 & .496 & - \\
& 7 ve üzeri & 35 & 53.79 & & & & \\
\hline
\end{tabular}

Tablo 18 incelendiğinde, 1-3, 4-6, 7 ve üzeri yıllar arasında anlamlı fark bulunmadı söylenebilir. Buna göre elde edilen verilerin bağımlı öğrenme stilinde düzenli piyano çalma yılı değişkenine göre anlamlı fark oluşturmadığı görülmektedir.

Tablo 19: Bağımlı Öğrenme Stilinin İkiden Fazla Gruplu Değişkenler Üzerinde Anlamlılık Düzeyi

\begin{tabular}{|c|c|c|c|c|c|c|c|}
\hline Değişkenler & Gruplar & $\mathrm{n}$ & $\begin{array}{c}\text { Sinif } \\
\text { Ortalaması } \\
\end{array}$ & $\mathrm{sd}$ & $X^{2}$ & $\mathrm{p}$ & Fark \\
\hline Eğitimi & 1 Öğrt. & 17 & 69.53 & & & & \\
\hline Süresince & 2 Öğrt. & 43 & 50.08 & & & & \\
\hline Çalışılan & 3 Öğrt. & 31 & 66.61 & 4 & 6.089 & .193 & - \\
\hline Piyano & 4 Öğrt. & 20 & 59.90 & & & & \\
\hline Öğretmeni & 5 Öğrt. & 7 & 60.36 & & & & \\
\hline
\end{tabular}


Bağımlı öğrenme stilini tercih eden öğrencilerin, tablo 19'a göre eğitimi süresince çalıştığ piyano öğretmeni değişkeninde anlamlı bir fark oluşturmadığg görülmüştür.

Tablo 20: Duyuşsal Öğrenme Stilinin İkili Gruplu Değişkenler Üzerinde Anlamlılık Düzeyi

\begin{tabular}{cccccccc}
\hline Değiş̧kenler & Gruplar & $\mathrm{N}$ & $\begin{array}{c}\text { Sira } \\
\text { Ortalamas }\end{array}$ & Sira Toplamı & $\mathrm{U}$ & $\mathrm{Z}$ & $\mathrm{p}$ \\
\hline \multirow{2}{*}{ Cinsiyet } & Kiz & 64 & 56.49 & 3615.50 & 1535.500 & -.1045 & .296 \\
\hline & Erkek & 54 & 63.06 & 3405.50 & 2960 \\
\hline
\end{tabular}

Duyuşsal öğrenme stiline sahip öğrencilerin, cinsiyet değişkeni üzerinde anlamlı bir fark oluşturup oluşturmadığına bakılmıştır. Tablo 20'ye göre, anlamlı bir fark $(\mathrm{p}=.296)$ bulunmadığ görülmüştür. Buna göre cinsiyet değişkeninin piyano öğreniminde bağımsız öğrenme stili üzerinde bir fark oluşturmadığ 1 görülmüştür.

Tablo 21: Duyuşsal Öğrenme Stilinin İkili Gruplu Değişkenler Üzerinde Anlamlılık Düzeyi

\begin{tabular}{clcccccc}
\hline Değişkenler & Gruplar & $\mathrm{N}$ & $\begin{array}{c}\text { Sira } \\
\text { Ortalaması }\end{array}$ & Sıra Toplamı & U & Z & p \\
\hline \multirow{2}{*}{$\begin{array}{c}\text { Mezun Olduğu } \\
\text { Lise }\end{array}$} & $\begin{array}{l}\text { Güzel } \\
\text { Sanatlar }\end{array}$ & 86 & 56.92 & 4895.50 & & \\
& Diğer & 32 & 66.42 & 2125.50 & & -1.348 & .178 \\
\hline
\end{tabular}

Duyuşsal öğrenme stiline sahip öğrencilerin, mezun olduğu lise değişkeni üzerinde anlamlı bir fark oluşturup oluşturmadığına bakılmıştır. Tablo 21'e göre, anlamlı bir fark $(p=.178)$ bulunmadığı görülmüştür. Buna göre mezun olduğu lise değişkeninin piyano öğreniminde bağımsız öğrenme stili üzerinde bir fark oluşturmadığı söylenebilir.

Tablo 22: Duyuşsal Öğrenme Stilinin İkili Gruplu Değişkenler Üzerinde Anlamlılık Düzeyi

\begin{tabular}{cccccccc}
\hline Değişkenler & Gruplar & $\mathrm{N}$ & $\begin{array}{c}\text { Sira } \\
\text { Ortalamas }\end{array}$ & Sira Toplamı & $\mathrm{U}$ & $\mathrm{Z}$ & $\mathrm{p}$ \\
\hline Özel Piyano Dersi & Hayır & 104 & 61.13 & 6357.00 & 559.500 & -1.414 & .157 \\
Alma Durumu & Evet & 14 & 47.43 & 664.00 & & \\
\hline
\end{tabular}

Duyuşsal öğrenme stiline sahip öğrencilerin, özel piyano dersi alma durumu değişkeni üzerinde anlamlı bir fark oluşturup oluşturmadığına bakılmıştır. Tablo 22'ye göre, anlamlı bir fark $(\mathrm{p}=.157)$ bulunmadığı görülmüştür. Buna göre özel piyano dersi alma durumu değişkeninin piyano öğreniminde duyuşsal öğrenme stili üzerinde bir fark oluşturmadığı görülmüştür.

Tablo 23: Duyuşsal Öğrenme Stilinin İkiden Fazla Gruplu Değişkenler Üzerinde Anlamlılık Düzeyi

\begin{tabular}{cccccccc}
\hline Değişkenler & Gruplar & $\mathrm{n}$ & $\begin{array}{c}\text { Sinıf } \\
\text { Ortalaması }\end{array}$ & sd & $\mathrm{X}^{2}$ & $\mathrm{p}$ & Fark \\
\hline Düzenli Piyano & $1-3$ yıl & 40 & 65.99 & \multirow{2}{*}{2} & .2594 & .273 & - \\
Çalma Y1lı & $4-6$ yıl & 43 & 58.36 & 2 & .259 & & \\
\hline
\end{tabular}

Tablo 23 incelendiğinde, elde edilen verilerin düzenli piyano çalma yılı değişkeni duyuşsal öğrenme stilinde anlamlı fark ( $\mathrm{p}=.273)$ oluşturmadığı görülmektedir. 
Tablo 24: Duyuşsal Öğrenme Stilinin İkiden Fazla Gruplu Değişkenler Üzerinde Anlamlılık Düzeyi

\begin{tabular}{|c|c|c|c|c|c|c|c|}
\hline Değişkenler & Gruplar & $\mathrm{n}$ & $\begin{array}{c}\text { Sinif } \\
\text { Ortalamas1 }\end{array}$ & sd & $\mathrm{X}^{2}$ & $\mathrm{p}$ & Fark \\
\hline Eğitimi & 1 Öğgrt. & 17 & 60.12 & & & & \\
\hline Süresince & 2 Öğrt. & 43 & 55.44 & & & & \\
\hline Çalışılan & 3 Öğrt. & 31 & 58.85 & 4 & 2.089 & .719 & - \\
\hline Piyano & 4 Öğrt. & 20 & 68.70 & & & & \\
\hline Öğretmeni & 5 Öğrt. & 7 & 59.50 & & & & \\
\hline
\end{tabular}

Duyuşsal öğrenme stilini tercih eden öğrencilerin, tablo 24'e göre eğitimi süresince çalıştığı piyano öğretmeni değişkeninde anlamlı bir fark ( $p=.719)$ oluşturmadığı söylenebilir.

Tablo 25: Piyano Dersine Yönelik Tutum Ölçeği Hoşnutluk Alt boyutunun İkili Gruplu Değişkenler Üzerinde Anlamlılık Düzeyi

\begin{tabular}{|c|c|c|c|c|c|c|c|}
\hline Değişkenler & Gruplar & $\mathrm{n}$ & $\begin{array}{c}\text { Sira } \\
\text { Toplamı }\end{array}$ & $\begin{array}{c}\text { Sira } \\
\text { Ortalamas1 } \\
\end{array}$ & $\mathrm{U}$ & $\mathrm{Z}$ & $\mathrm{p}$ \\
\hline Cinsiyet & $\begin{array}{l}\text { K1z } \\
\text { Erkek }\end{array}$ & $\begin{array}{l}64 \\
54\end{array}$ & $\begin{array}{l}63.69 \\
54.54\end{array}$ & $\begin{array}{l}4076.00 \\
2945.00\end{array}$ & 1460.0 & -1.448 & .148 \\
\hline $\begin{array}{l}\text { Mezun Olduğu } \\
\text { Lise }\end{array}$ & $\begin{array}{l}\text { Güzel } \\
\text { Sanatlar } \\
\text { Diğer }\end{array}$ & 86 & 57.78 & $\begin{array}{l}85612.0 \\
26489.0\end{array}$ & 1228.0 & -.896 & .370 \\
\hline $\begin{array}{c}\text { Özel Piyano Dersi } \\
\text { Alma D. }\end{array}$ & $\begin{array}{l}\text { Hayır } \\
\text { Evet }\end{array}$ & $\begin{array}{c}104 \\
14\end{array}$ & $\begin{array}{l}58.84 \\
64.39\end{array}$ & $\begin{array}{l}6119.50 \\
901.50\end{array}$ & 659.500 & -.570 & .568 \\
\hline
\end{tabular}

Piyano dersine yönelik tutum ölçeğinin hoşnutluk alt boyutu ikili değişkenlere göre, cinsiyet, mezun olduğu lise, özel piyano dersi alma durumu üzerinde anlamlı bir fark oluşturup oluşturmadığına bakılmıştır. Tablo 25'e göre, cinsiyet, mezun olduğu lise, özel piyano dersi alma durumu anlamlı bir fark bulunmadığı görülmüsştür.

Tablo 26: Piyano Dersine Yönelik Tutum Ölçeği Hoşnutluk Alt boyutunun İkiden Fazla Gruplu Değişkenler Üzerinde Anlamlılık Düzeyi

\begin{tabular}{|c|c|c|c|c|c|c|c|}
\hline Değişkenler & Gruplar & $\mathrm{n}$ & $\begin{array}{c}\text { Sinif } \\
\text { Ortalamas } 1\end{array}$ & $\mathrm{sd}$ & $\mathrm{X}^{2}$ & $\mathrm{p}$ & Fark \\
\hline \multirow{3}{*}{$\begin{array}{l}\text { Düzenli Piyano } \\
\text { Çalma Y1lı }\end{array}$} & $1-3$ y1l & 40 & 60.95 & \multirow{3}{*}{2} & \multirow{3}{*}{1.048} & \multirow{3}{*}{.592} & \multirow{3}{*}{-} \\
\hline & $4-6$ y1l & 43 & 55.37 & & & & \\
\hline & 7 ve üzeri & 35 & 62.91 & & & & \\
\hline Eğitimi & 1 Öğrt. & 17 & 67.47 & \multirow{5}{*}{4} & \multirow{5}{*}{3.909} & \multirow{5}{*}{.418} & \multirow{5}{*}{ - } \\
\hline Süresince & 2 Öğrt. & 43 & 64.60 & & & & \\
\hline Çalışılan & 3 Öğrt. & 31 & 53.29 & & & & \\
\hline Piyano & 4 Öğrt. & 20 & 55.08 & & & & \\
\hline Öğretmeni & 5 Öğrt. & 7 & 48.93 & & & & \\
\hline
\end{tabular}

Tablo 26'ya göre elde edilen verilere bakıldığında, düzenli piyano çalma y1lı, eğitimi süresince çalışılan piyano dersi değişkenlerinin piyano dersine yönelik tutum ölçeğinin hoşnutluk alt boyutunda anlamlı fark oluşturmadığı söylenebilir. 
Tablo 27: Piyano Dersine Yönelik Tutum Ölçeği Değer Alt boyutunun İkili Gruplu Değişkenler Üzerinde Anlamlılık Düzeyi

\begin{tabular}{|c|c|c|c|c|c|c|c|}
\hline Değişkenler & Gruplar & $\mathrm{n}$ & $\begin{array}{c}\text { Sira } \\
\text { Toplamı }\end{array}$ & $\begin{array}{c}\text { Sira } \\
\text { Ortalamas1 } \\
\end{array}$ & $\mathrm{U}$ & $\mathrm{Z}$ & $\mathrm{p}$ \\
\hline Cinsiyet & $\begin{array}{l}\text { Kiz } \\
\text { Erkek }\end{array}$ & $\begin{array}{l}64 \\
54\end{array}$ & $\begin{array}{l}63.56 \\
54.69\end{array}$ & $\begin{array}{l}4068.00 \\
2953.00\end{array}$ & 1468.0 & -1.405 & .160 \\
\hline $\begin{array}{l}\text { Mezun Olduğu } \\
\text { Lise }\end{array}$ & $\begin{array}{l}\text { Güzel } \\
\text { Sanatlar } \\
\text { Diğer }\end{array}$ & 86 & 58.70 & $\begin{array}{l}5048.50 \\
1972.50\end{array}$ & 1307.500 & -.415 & .678 \\
\hline $\begin{array}{c}\text { Özel Piyano Dersi } \\
\text { Alma D. }\end{array}$ & $\begin{array}{l}\text { Hayır } \\
\text { Evet }\end{array}$ & $\begin{array}{c}104 \\
14\end{array}$ & $\begin{array}{l}60.33 \\
53.32 \\
\end{array}$ & $\begin{array}{c}6274.50 \\
746.50 \\
\end{array}$ & 641.500 & -.720 & .471 \\
\hline
\end{tabular}

Piyano dersine yönelik tutum ölçeğinin değer alt boyutu ikili değişkenlere göre, cinsiyet, mezun olduğu lise, özel piyano dersi alma durumu üzerinde anlamlı bir fark oluşturup oluşturmadığına bakılmıştır. Tablo 27'ye göre, cinsiyet, mezun olduğu lise, özel piyano dersi alma durumu anlamlı bir fark bulunmadığı söylenebilir.

Tablo 28: Piyano Dersine Yönelik Tutum Ölçeği Değer Alt boyutunun İkiden Fazla Gruplu Değişkenler Üzerinde Anlamlılık Düzeyi

\begin{tabular}{|c|c|c|c|c|c|c|c|}
\hline Değişkenler & Gruplar & $\mathrm{n}$ & $\begin{array}{c}\text { Sinif } \\
\text { Ortalamas1 } \\
\end{array}$ & $\mathrm{sd}$ & $X^{2}$ & $\mathrm{p}$ & Fark \\
\hline \multirow{3}{*}{$\begin{array}{l}\text { Düzenli Piyano } \\
\text { Çalma Yılı }\end{array}$} & $1-3$ y1l & 40 & 59.18 & \multirow{3}{*}{2} & \multirow{3}{*}{.082} & \multirow{3}{*}{.960} & \multirow{3}{*}{ - } \\
\hline & $4-6$ y1l & 43 & 58.70 & & & & \\
\hline & 7 ve üzeri & 35 & 60.86 & & & & \\
\hline Eğitimi & 1 Öğrt. & 17 & 57.79 & \multirow{5}{*}{4} & \multirow{5}{*}{5.596} & \multirow{5}{*}{.231} & \multirow{5}{*}{ - } \\
\hline Süresince & 2 Öğ̆rt. & 43 & 68.79 & & & & \\
\hline Çalışılan & 3 Öğ̆rt. & 31 & 55.47 & & & & \\
\hline Piyano & 4 Öğrt. & 20 & 49.68 & & & & \\
\hline Öğretmeni & 5 Öğrt. & 7 & 52.50 & & & & \\
\hline
\end{tabular}

Tablo 28' e göre elde edilen verilere bakıldığında, düzenli piyano çalma y1lı, eğitimi süresince çalışılan piyano dersi değişkenlerinin piyano dersine yönelik tutum ölçeğinin değer alt boyutunda anlamlı fark oluşturmadığı söylenebilir.

\section{Araştırmanın Dördüncü Alt Problemine Ait Bulgular ve Yorum}

Araştırmanın dördüncü alt problemi "Öğrencilerin öğrenme stil puanları ile piyano tutum düzeyleri arasındaki ilişki ne düzeydedir?” biçiminde oluşturulmuştur. Araştırmanın dördüncü alt problemine göre yapılan analizler sonucunda, öğrencilerin öğrenme stilleri ile piyano dersine yönelik tutum ölçeğinin alt boyutları arasındaki analizlerine bakılmıştır. Aralarındaki korelasyona bakabilmek Sperman korelasyon analizi uygulanmıştır. 1.00 olan korelasyon katsayısı mükemmel pozitif; -1.00 olan korelasyon katsayısı mükemmel negatif; 0.00 olan korelasyon katsayısı, ilişki olmadığını ifade eder. Korelasyon katsayısı, 0.70-1.00 ise yüksek; 0.70-0.30 arası ise orta; 0.300.00 arası ise, düşük düzeyde bir ilişki biçiminde ifade edilelebilir (Büyüköztürk, 2015). 
Tablo 29:Öğrencilerin öğrenme stil puanları ile piyano tutum düzeyleri arasındaki ilişki

\begin{tabular}{|c|c|c|c|c|c|c|c|}
\hline & & Bağımsız & Analitik & Bağımlı & Duyuşsal & Hoşnutluk & Değer \\
\hline Bağımsız & $\begin{array}{c}\text { Korelasyon } \\
\mathrm{p}\end{array}$ & 1.00 & & & & & \\
\hline Analitik & $\begin{array}{c}\text { Korelasyon } \\
\mathrm{p}\end{array}$ & $\begin{array}{l}.351 \\
.000 \\
\end{array}$ & 1.00 & & & & \\
\hline Bağımlı & $\begin{array}{c}\text { Korelasyon } \\
\text { p }\end{array}$ & $\begin{array}{l}.044 \\
.636\end{array}$ & $\begin{array}{l}.118 \\
.203\end{array}$ & 1.00 & & & \\
\hline Duyuşsal & $\begin{array}{c}\text { Korelasyon } \\
\mathrm{p}\end{array}$ & $\begin{array}{r}-.089 \\
.338 \\
\end{array}$ & $\begin{array}{l}.057 \\
.541 \\
\end{array}$ & $\begin{array}{l}.083 \\
.373 \\
\end{array}$ & 1.00 & & \\
\hline Hoşnutluk & $\begin{array}{c}\text { Korelasyon } \\
\text { p }\end{array}$ & $\begin{array}{l}.568 \\
.000\end{array}$ & $\begin{array}{l}.335 \\
.000\end{array}$ & $\begin{array}{l}-.153 \\
.098\end{array}$ & $\begin{array}{r}-.022 \\
.812\end{array}$ & 1.00 & \\
\hline Değer & $\begin{array}{c}\text { Korelasyon } \\
\text { p }\end{array}$ & $\begin{array}{l}-.447 \\
.000\end{array}$ & $\begin{array}{l}-.250 \\
.006\end{array}$ & $\begin{array}{l}.206 \\
.025\end{array}$ & $\begin{array}{l}-.062 \\
.505\end{array}$ & $\begin{array}{l}-.792 \\
.000\end{array}$ & 1.00 \\
\hline
\end{tabular}

$\mathrm{N}=118, \mathrm{p}<0.01$

Tablo 29'a bakıldığında bağımsız öğrenme stilini tercih eden öğrencilerin piyano dersine yönelik tutum düzeyi hoşnutluk alt boyutu arasındaki korelasyon katsayısının .568 olduğu görülmektedir. Bu değere göre orta düzeyde bir ilişki olduğu söylenebilir. Değer alt boyutunun korelasyon katsayısının -.447 olduğu görülmektedir. Bu değere göre negatif yönde orta düzeyde ilişki sonucu çıktığı söylenebilir. Korelasyon düzeyinin. 01 düzeyinde anlamlı çıkması ise bu ilişkiyi destekler niteliktedir. Bağımsız öğrenme stilini tercih edenlerin puanları ile hoşnutluk alt boyutu arasında pozitif yönde doğru orantılı bir ilişki varken, değer alt boyutuna ilişkin puanlar incilendiğinde negatif yönde orta düzey ilişki olduğu söylenebilir. Buna göre bağımsız öğrenme stilini tercih eden öğrencilerin piyano çalgısına yönelik hoşnutluk tutumu pozitif yönde ilişki gösterirken aynı ilişki değer alt boyutu için söylenemez.

Analitik öğrenme stilini tercih eden öğrencilerin, hoşnutluk alt boyutunda korelasyon katsayısının .335 olduğu görülmektedir. Buna göre orta düzeyde bir ilişki görülmektedir, elde edilen sonucun düşük düzeyde bir ilişkiye yakın olduğu söylenebilir. Değer alt boyutu katsayısı .250 olarak görülmektedir. Bu sonuca göre, analitik öğrenme stilini tercih eden öğrencilerin piyano dersi tutum ölçeği değer alt boyutunda negatif yönde düşük bir ilişki sonucu olduğu görülmektedir.

Bağımlı öğrenme stilini incelendiğinde, hoşnutluk alt boyutunda korelasyon katsayısının .153 olduğu görülmektedir. Bu sonuç değerlendirildiğinde piyano dersi tutum ölçeği hoşnutluk alt boyutunda negatif yönde düşük bir ilişki çıktığı, değer alt boyutuna göre ise (.206) pozitif yönde düşük bir ilişki sonucu söylenebilir.

Duyuşsal öğrenme stiline sahip öğrencilerin hoşnutluk alt boyutunda korelasyon katsayısının -.022 olduğu görülmektedir. Bu sonuç negatif yönde düşük bir ilişki sonucunu ifade etmektedir. Değer alt boyutu korelasyon katsayısının -.062 olduğu görülmektedir. Bu değer duyuşsal öğrenme stili ile değer alt boyutu arasında negatif yönde düşük bir ilişki var olduğu sonucunu ifade edebilir.

\section{Tartışma Ve Öneriler}

\section{Tartışma}

$\mathrm{Bu}$ araştırmada, Pamukkale Üniversitesi, Müzik Eğitimi Anabilim Dalı öğrencilerinin öğrenme stillerinin belirlenmesi, piyano dersine yönelik tutumlarının ölçülmesi ve karşılaştırılması amaçlanmıştır. Yapılan incelemeler sonunda öğrencilerin piyano öğrenme stillerinde daha çok duyuşsal öğrenme stilini tercih ettikleri söylenebilir. Öğrencilerin piyano öğrenme stilleri ile piyano dersine yönelik tutumları arasında genelde düşük düzey ilişki sonucu olduğu söylenebilir. 
Bağımsız öğrenme stilini tercih eden öğrencilerin, belirlenmiş olan değişkenler ile arasında anlamlı fark görülmemiştir. Buna göre belirlenen değişkenler bağımsız öğrenme stilini tercih eden öğrenciler üzerinde anlamlı bir fark yaratmadığı söylenebilir. Bu araştırma sonucuna göre, piyano öğrenme stili ile piyano dersine yönelik tutum arasında yükssek bir ilişki olmadığ 1 sonucu çıkmıştır.

Tuzcu (2016) yapmış olduğu doktora tezinde, belirlemiş olduğu öğrencilerin piyano eğitiminde özdüzenlemeli öğrenme düzeyleri; yaş, cinsiyet, çalışma süresi ana dal, öğrenim gördükleri fakülte türü, mezun oldukları lise, öğretmenden memnuniyet, piyano geçmişi ve piyano başarı algılarına göre anlamlı fark bulduğunu ifade etmektedir. Tuzcu'nun (2016) ulaştığı bu bulgular, yapılan bu çalışmanın sonuçları ile birbirini destekler nitelikte değildir.

Analitik öğrenme stilini tercih eden öğrencilerin, özel piyano dersi alma durumu değiş̧keninde, ders almayan öğrenciler lehine anlamlı fark çıktığı, belirlenmiş diğer değişkenler ile arasında anlamlı fark çıkmadığı görülmüştür. Analitik öğrenme stili ile piyano tutumu arasında yüksek düzeyde bir ilişki olmadığı sonucu ortaya çıkmıştır.

Bağımlı öğrenme stilinindeki öğrencilerin, cinsiyet değişkeni üzerinde erkek öğrencilerinin lehine anlamlı fark çıktığı görülmektedir. Belirlenmiş diğer değişkenler ile arasında anlamlı fark görülmemiştir. Bağımlı öğrenme stili ile piyano tutumunda düşük bir ilişki sonucu olduğu söylenebilir.

Duyuşsal öğrenme stilini tercih eden öğrencilerin, belirlenmiş değişkenler ile arasında anlamlı fark görülmemiştir. Duyuşsal öğrenme stili ile piyano tutumu arasındaki ilişki düşük düzeyde bir ilişki biçimde ifade edilebilir.

Öğrencilerin öğrenme stillerini belirlemek ve bu yönde düzenlenecek olan eğitimin öğrenci başarılarına olumlu yönde etkili olacağı söylenebilir. Sapancı (2014) yapmış olduğu çalışmasında, öğrencilerin öğrenme stillerine göre akademik başarılarının farklılaştığı sonucunu bulduğunu ifade etmiştir.

Bu çalıșmada müzik öğretmeni adaylarının piyano öğrenme stilleri ile piyano dersine yönelik tutumları karşılaştırılmıştır. Elde edilen bulgulara göre yüksek düzeyde ilişki olmadığı söylenebilir. Bu bulgu, çeşitli sebeplerden dolayı gerçekleşmiş olabilir. Bu sebepler öğrencilerin derse karşı tutumları, öğretmen değişikliğinin vermiş olduğu rahatsızlık gibi buna benzer değişiklikler olabilir. Dört yıl boyunca öğrencilerin derslerde yaşadıkları inişli çıkışlı çizgileri, öğretmenleri ile iletişimleri, aldıkları eserlere karşı yaklaşımları, çalgıyı sevme durumları vb. gibi etkiler bunlardan bazıları olabilir. Farklı örneklem grupları ile piyano öğrenme stillerinin piyano dersi başarısına ya da akademik başarıya etkileri araştırılabilir. $\mathrm{Bu}$ araştırma, başka örneklem grupları ile belirlenen farklı değişkenler üzerinde, başka sonuçlar verebilir.

\section{Kaynakça}

Arkonaç, S. A. (2011). Sosyal pisikoloji. Alfa Basım Yayım Dağıtım San. ve Tic. Ltd. Şti.

Aşkar, P., \& Akkoyunlu, B. (1993). Kolb Öğrenme Stili Envanteri. Eğitim ve Bilim. 37-47.

Atılgan, H., Kan, A., Doğan, N. \& (Ed.) Hakan Atılgan, (2015). Madde ve test istatistiklerieğitimde ölçme ve değerlendirme. Anı Yayınc1l1k. https://doi.org/10.21031/epod.346650.

Boydak, A. (2014). Öğrenme stilleri. Beyaz Yayınları.

Büyüköztürk, Ş. (2015). Sosyal bilimler için veri analizi el kitabl. Pegem Akademi. https://doi.org/10.14527/9789756802748.

Büyüköztürk, Ş., Çakmak, E. K., Akgün, Ö. E., Karadeniz, Ş., \& Demirel, F. (2015). Bilimsel araştırma yöntemleri. Pegem Akademi. https://doi.org/10.14527/9789944919289. 
Can, A. (2014). SPSS ile bilimsel araştırma sürecinde nicel veri analizi. Pegem Akademi. https://doi.org/10.14527/9786053644484.

Demirtaş, S., \& Süral, S. (2018). Development Of Pamukkale Piano Learning Style Scale. International Journal Assessment Tools in Education, 90-104. https://doi.org/10.21449/ijate.339492

Ertem, Ş. (2014). Piyano Eğitiminde Öğrenme Süreci ve Öğretme Stratejileri Kullanmanın Yeri ve Önemi. Sanat Eğitimi Dergisi, 1-26. https://doi.org/10.15869/itobiad.629732.

Gencel, E.İ. (2007). Kolb’un Deneyimsel Öğrenme Kuramına Dayalı Öğrenme Stilleri EnvanteriIII'ü Türkçeye Uyarlama Çalışması. Dokuz Eylül Üniversitesi Sosyal Bilimler Enstitüsü Dergisi, 9 (2) 120-139. https://doi.org/10.16953/deusosbil.332763.

Koçak, T. (2007). İlköğretim 6.7.8. Sinıf Öğrencilerinin Öğrenme Stilleri ve Akademik Başarıları Arasındaki İlişskinin İncelenmesi. [Yayımlanmamış doktora tezi]. Gaziantep Üniversitesi. https://doi.org/10.29228/rssstudies.13258.

Kurtuldu, M. K., \& Aksu, C. (2015). Müzik Öğretmeni Adaylarının Öğrenme Stillerinin Çeşitli Değișkenlere Göre Değerlendirilmesi. Sanat Eğitimi Dergisi. 3(2), 1-23. http://dx.doi.org/10.7816/sed-03-02-01

Sapancı, A. (2014). Öğretmen Adaylarının Öğrenme Stileri İle Akademik Başarıları Arasındaki İlişki. Asya Öğretim Dergisi, 60-68. https://doi.org/10.21733/ibad.704886.

Senemoğlu, N. (2005). Gelişim öğrenme ve öğretim. Gazi Kitabevi.

Şeker Sır, N., Karataş H., \& Çeliköz N. (2015). Öğretmen Adaylarının Öğrenme Stili Tercihlerine İlişkin Bir İnceleme. Educational Sience, 10(4), 237-252. http://dx.doi.org/10.12739/NWSA.2015.10.4.1C0645

Tavşanc1l, E. (2014). Tutumların ölçülmesi ve spss ile veri analizi. Nobel Akademik Yayıncılık Eğitim Danışmanlık Tic. Ltd. Şti.

Tufan, E., \& Güdek, B. (2008). Piyano Dersi Tutum Ölçeğinin Geliştirilmesi. Gazi Üniversitesi Gazi Eğitim Fakültesi Dergisi 28 (1) , 75-90. https://doi.org/10.17152/gefad.540943.

Tuzcu, Ö. (2016). Piyano Ĕgitiminde Özdüzenlemeli Öğrenme Ve Öğrenme Stilleri İle Akademik Başarı Arasındaki İlişki. [Yayımlanmamış doktora tezi]. İstanbul Üniversitesi. https://doi.org/10.17860/efd.37220.

Veznedaroğlu, R. L., \& Özgür, A. (2005). Öğrenme Stilleri: Tanımlamalar Modeller ve İşlevleri. Illkögretim Online, 4(2) 1-16.

Zahal, O. (2014). Özel Yetenek SinavinaGiren Öğrencilerin Öğrenme Stilleri ve Bilişsel Esneklik Düzeyleri ile Sınav Başarıları Arasındaki İlişki. [Yayımlanmamış doktora tezi]. İnönü Üniversitesi. https://doi.org/10.17679/inuefd.298059. 